Wyższa Szkoła Promocji w Warszawie

Wydziat Zarządzania

Agnieszka Wiśniewska

\title{
MECHANIZM ODDZIAŁYWANIA WIZERUNKU MARKI NA ZACHOWANIA KONSUMENTÓW
}

Z a rys treści. Marka z punktu widzenia przedsiębiorstw stanowi jeden $\mathrm{z}$ kluczowych elementów oferty rynkowej i konkurowania. Przedsiębiorstwa podejmują działania ukierunkowane na kreowanie wizerunku, jednak zasadność tych działań potwierdzić może tylko pełne wykorzystanie potencjału umieszczonego w wykreowanym wizerunku. Autorka stawia tezę, że marka, a konkretnie jej wizerunek, jest istotnym czynnikiem wpływającym na zachowania i decyzje zakupowe konsumentów, a szereg funkcje rynkowe przypisywane marce realizowane są przez cechy wizerunku.

Słow a kluczow e: wizerunek marki, zachowania konsumentów, postawy.

\section{WSTĘP}

Początki stosowania marki, jako sposobu na oznakowanie produktu danego producenta sięgają, według badaczy tego zagadnienia, przynajmniej XVI wieku. Wydaje się także, że podstawowym zadaniem owego oznaczenia było wówczas identyfikowanie produktu z producentem (Kall, 2001, s. 11), jednak potencjał drzemiący w tym rozwiązaniu szybko sprawił, że dziś marka jest jednym z kluczowych instrumentów konkurowania na rynku przedsiębiorstw 
produkcyjnych i usługowych, terytoriów, organizacji non-profit, a także partii i osób na arenie politycznej. Próbując doprecyzować pojęcie marki, w literaturze napotyka się dwa nurty. W pierwszym marka definiowana jest jako zbiór atrybutów instrumentalnych jak nazwa, termin, znak, symbol, rysunek lub ich kombinacja (wszelkie definicje za: American Marketing Association), w drugim do marki podchodzi się holistycznie jako do pewnego zjawiska obejmującego produkt oznaczony konkretną nazwą wraz z jego opakowaniem, charakterystycznym sposobem promowania się, dostępnego w typowych dla niego miejscach, i objętego spójną strategią cenową, a także wartości i skojarzenia (Altkorn, 2001, s. 11; Edwards, Day, 2006, s. 50).

Wielu autorów podejmuje dyskusję nad zasadnością tych nurtów, niemniej nie to będzie przedmiotem niniejszego artykułu. Jakkolwiek by nie podchodzić do definiowania marki, zawsze $\mathrm{w}$ definicji pojawi się nazwa oraz pewne związane z nią atrybuty oraz przypisane tej złożonej konstrukcji funkcje identyfikacji i wyróżnienia. W najprostszym ujęciu markę zatem można za Grzegorczykiem zdefiniować jako nazwę (Grzegorczyk, 2005, s. 12). Bezspornie też nazwa będzie pełniła funkcję identyfikacyjną, być może także odróżniającą, ale już niekoniecznie wyróżniającą. Z kolei pozostałe atrybuty, zarówno te instrumentalne, jak i wynikowe, będące konsekwencją funkcjonowania marki, pełnić będą szereg funkcji dodatkowych, przesądzających o potencjale całego zbioru atrybutów marki w strategii konkurowania o klientów.

Niniejszy artykuł poświęcony jest wizerunkowi marki, a zatem pewnemu jej obrazowi, wyobrażeniu o niej, sposobowi postrzegania, pojmowania lub też interpretacji cech jej tożsamości. Wizerunek pojawia się w holistycznych definicjach marki jako atrybut wynikowy. Urbanek, posługując się definicją instrumentalną marki za Kotlerem, stwierdza na koniec, że marka obejmuje także wrażenia, jakie konsumenci odnoszą, użytkując produkty nią oznaczone (Urbanek, 2002, s. 14). Altkorn markę odnosi do obrazu, będącego konsekwencją przeświadczenia konsumentów o korzyściach oferowanych przez produkty objęte daną marką (Altkorn, 2001, s. 11). H. Edwards i D. Day odwołują się w definicji marki do wartości i skojarzeń (Edwards, Day, 2006, s. 50).

\section{WIZERUNEK MARKI - ZAGADNIENIA DEFINICYJNE}

Wizerunek rozumiany może być jako synteza doświadczeń, odczuć, wartości, przekonań i aspiracji w stosunku do danego obiektu (Dobni \& Zinkhan, 1990, za: Cian, 2011, s. 165). To konstrukcja tworzona przez emocjonalne i funk- 
cjonalne elementy (Kennedy, 1977; Palacio, 2002, za: Cian, 2011, s. 165). Kall wskazuje, że wizerunek jest efektem działań komunikacyjnych danej marki (firmy w stosunku do danej marki), jest syntezą emitowanych przez markę sygnałów (Kall, 2001, s. 25), Kozłowska uzupełnia, że owe działania komunikacyjne mogą z punktu widzenia firmy być świadome i celowe lub też nieuświadomione (Kozłowska, 2011, s. 314).

Kłeczek podkreśla, że wizerunek marki powstaje wskutek skojarzeń związanych z sytuacją zakupową i potem warunkami użytkowania, nabywanym doświadczeniem, cechami produktu oraz korzyściami, jakie ów produkt dostarcza konsumentowi (funkcjonalnymi, symbolicznymi), a także ostatecznie z osobowością marki. (Kłeczek, 2006, s. 15). Z pojęciem wizerunku wiąże się zatem kognitywna reprezentacja pewnego realnego obiektu w umysłach adresatów komunikatu o obiekcie (Capriotti, 1999; Da Silva \& Syed Alwi, 2008, za: Chia-Hung, 2008, s. 239), ale też bardzo często jego kreowanie opiera się na elementach afektywnych (Grzegorczyk, 2005, s. 150). Wskazuje się, że wizerunek marki to wyobrażenie o niej powiązane ze skojarzeniami utrzymywanymi w pamięci (Keller 1993, za: Chia-Hung, 2008, s. 239) oraz ostatnim doświadczeniem konsumpcyjnym, co przemawia za tezą, że wizerunek marki, będąc względnie trwały w czasie (Grzegorczyk, 2010 s. 65), będzie jednocześnie różnił się w świadomościach poszczególnych indywidualnych konsumentów. Wizerunek jest wrażeniem powstałym pod wpływem postrzeganej reputacji producenta, skojarzeń związanych z nazwą marki, odbioru treści reklamowych, form i mediów reklamy, ale też użytkowania produktu (Pars, Gulsel, 2011, s. 228). Okazuje się kategorią abstrakcyjną, złożoną, pozostającą pod wpływem wielu czynników, a zatem z perspektywy różnych odbiorców - niejednorodną.

\section{WPŁYW WIZERUNKU NA POSTAWY WZGLĘDEM MARKI}

W strategii rynkowej przedsiębiorstw wizerunek marki odgrywa ważną, choć niedoprecyzowaną rolę, stąd też liczne publikacje poruszają problem kreowania wizerunku marki, a podmioty rynkowe podejmują działania ukierunkowane na kreowanie i kontrolowanie tegoż atrybutu. Pojawia się jednak zasadnicze pytanie o cel tych działań - w czym przejawia się efekt oddziaływania wizerunku, na co oddziałuje wizerunek i wreszcie jaki jest mechanizm tego oddziaływania. Problem celowego kreowania wizerunku, by osiągnąć efekty zgodne z założeniami strategii marketingowej, podejmuje w jednej ze swoich publikacji Grzegorczyk (Grzegorczyk, 2005b, s. 143-158), coraz częściej 
wątek ten pojawia się też w publikacjach z zakresu marketingu terytorialnego i marketingu usług turystycznych (Pars, Gulsel, 2011, s. 227-239). Wydaje się zatem, że szczególnie w tych dziedzinach, gdzie produkt jest bardzo złożony (terytorium) lub niematerialny (usługa turystyczna), wizerunek marki staje się docenionym i wykorzystywanym instrumentem konkurowania. Z drugiej strony producenci produktów materialnych inwestują znaczne części budżetów właśnie w kreowanie wizerunku marki lub marek, intuicyjnie czując, że ta inwestycja się zwróci, jednak nie wykorzystują w pełni potencjału, jaki stworzyli w konkretnie ukształtowanym wizerunku marki.

Abstrahując jednak w tym momencie od możliwości celowego stosowania wizerunku marki jako instrumentu w strategii marketingowej, zastanowić się należy nad mechanizmem jego oddziaływania na zachowania konsumentów, cała bowiem strategia marketingowa zaczyna się i kończy na tym, co robią konsumenci. Analizując ten mechanizm dostrzec można aspekt poznawczy i aspekt emotywny. Budzyński, stawiając tezę, że wizerunek marki odgrywa istotną rolę w procesie decyzyjnym konsumenta, wyodrębnia dwie grupy jego komponentów. Obiektywne komponenty wizerunku dostarczają konsumentowi informacji o marce i oznaczonym nią produkcie. Subiektywne komponenty odwoływać się będą do emocji, przywołując odczucia i skojarzenia. Synergiczne oddziaływanie tych elementów ma wpłynąć na decyzję zakupową konsumenta (Budzyński, 2002, s. 19-20). Zakładając zatem, co już także wcześniej wynikło z prezentowanych do tej pory definicji, że wizerunek marki jest konstrukcją bazującą na elementach kognitywnych (zasoby wiedzy o marce, zdobyte na bazie doświadczenia lub pozyskane przez interpretację komunikatów o marce) oraz afektywnych (wszelkie odczucia, emocje, skojarzenia utrzymywane w pamięci), będzie on tworzył kongruentne komponenty postawy konsumenta wobec marki. Powstała na skutek tego względnie trwała ocena tej marki obejmie wytworzony na skutek dwóch pierwszych komponentów postawy (kognitywnego i afektywnego) element konatywy, związany z intencją czy też gotowością do określonego działania (poszukiwania marki, zakupu marki, przyznawania się do użytkowania marki, polecania marki).

Idąc tym tokiem rozumowania i próbując wyjaśnić znaczenie wizerunku marki w kształtowaniu się intencji behawioralnej i zachowania, należy odnieść się teraz do teorii zachowań nabywcy oraz relacji pomiędzy postawą a zachowaniem. Zasadniczo postawa wyjaśnia w znaczącej części zachowanie człowieka, a zmiana postawy powinna wiązać się ze zmianą zachowania. Zdarzają się jednak sytuacje, kiedy człowiek postępuje wbrew swojej postawie, ukształtowanej jako spójny twór wszystkich komponentów, lub wbrew jej wybranym komponentom, jeśli postawa nie stanowi spójnej kompozycji 
kognitywno-afektywno-konatywnej, co dotyczy raczej krótkiego okresu. W praktyce okazuje się, że może wystąpić blokada zmiany zachowania za sprawą działania przeciwstawnych postaw, presji sytuacji lub presji społecznej (Zimbardo, Leippe 2004, s. 237). W długim okresie z kolei zachowanie może prowadzić do zmiany postaw (Rudnicki, 2000, s. 83). Należy zwrócić uwagę na fakt, że zachowanie niezgodne $\mathrm{z}$ daną postawą jest konsekwencją przeciwstawnej postawy związanej z sytuacją, w jakiej znajduje się człowiek (presja sytuacji uaktywnia zatem także jakieś postawy). Można więc przyjąć, że każde zachowanie jest poprzedzone postawą, z tym że niekoniecznie wobec celu zachowania człowieka - może to być postawa wobec ryzyka, wobec zmian, wobec przestrzegania zasad w ogóle i inne.

\section{WIZERUNEK MARKI A MODELE ZACHOWAŃ NABYWCÓW}

Jeden z pierwszych modeli strukturalnych, całościowo ujmujący główne relacje pomiędzy postawą a zachowaniem, zaproponował w latach 60 . Francesco Nicosia. Nicosia umieszcza postawę w modelu zachowań konsumentów w pozycji efektu oddziaływania atrybutów firmy i jej działań komunikacyjnych kierowanych do konsumenta. Jednak zaznacza, że doświadczenie konsumenta w sposób istotny oddziałuje na jego predyspozycje. Synergia oddziaływania doświadczenia oraz komunikatów wysyłanych od firmy powoduje powstanie, utrwalenie lub modyfikację postawy, która dalej w modelu staje się fundamentem dla motywacji, a ta z kolei doprowadza do aktu zakupowego (Nicosia, 1968, s. 33). Wykorzystując tę teorię do potwierdzenia tezy o wpływie wizerunku marki na zachowania przez postawę, należy wskazać dwa kluczowe momenty. Po pierwsze oddziaływanie atrybutów marki, a zatem cech jej tożsamości, odbywa się przez komunikowanie tychże cech, co powoduje wytworzenie się w umyśle adresata komunikatu pewnego wyobrażenia o marce. Wyobrażenie to będzie bazowało na aspektach poznawczych i wywołanych przez komunikat emocjach, co spowoduje powstanie pewnej intencji w zakresie zachowania. To pierwszy etap oddziaływania wizerunku - wytworzenie postawy. Kolejny etap dotyczy już relacji pomiędzy postawą a zachowaniem. Wytworzona pod wpływem postawy i warunków decyzyjnych motywacja doprowadza do decyzji zakupowej i zakupu.

Znajomość postaw pozwala na przewidywanie zachowań tym precyzyjniej, im mniejszy jest udział czynnika spontaniczności. $Z$ tego punktu widzenia wskazuje się na dwie kategorie zachowań - spontaniczne i zaplanowa- 
ne. Przy przewidywaniu zachowania spontanicznego postawa powinna być uświadomiona i łatwo dostępna, w przeciwnym razie istnieje prawdopodobieństwo zachowania się pod wpływem czynników sytuacyjnych i oddziaływania społecznego (Maison, 2004, s. 16-18).

Znaczenie postawy jako predyktora planowanych zachowań konsumenckich wyjaśniane jest na gruncie teorii działania intencjonalnego. Wizerunek marki, kształtując postawy przez oddziaływanie na komponenty kognitywne i afektywne, stymulował będzie zatem zachowania intencjonalne. Potencjał jego wpływu należałoby zatem rozważać w świetle teorii zachowania celowego, w której prawdopodobieństwo wystąpienia określonego zachowania najlepiej określa się na podstawie intencji behawioralnych. Postawa będzie elementem ukierunkowującym intencje.

Do ważniejszych modeli, mających zasadniczy wkład w rozwój teorii zachowań konsumenckich, należy zaproponowany w latach 80. model Icka Ajzena i Martina Fishbeina. Autorzy przyjęli, że presja społeczna (normy zachowań) oraz postawa wobec konsekwencji zachowań determinują intencje behawioralne, które pozwalają na przewidywanie zachowań nabywcy (Ajzen, Fishbein, 1980, za: Zimbardo, Leippe, 2004, s. 236). Kolejne modele planowego działania rozwijają te relacje, wskazując na dodatkowe determinanty zachowania. Jedną z istotniejszych propozycji modyfikacji modelu Fishbeina i Ajzena zaprezentowali Perugini i Bagozzi, według których motywacyjny charakter komponentów postawy (a także przewidywanych konsekwencji postępowania, czyli oczekiwanych emocji i akceptacji społecznej związanej z normami subiektywnymi) kształtuje pragnienia, które są bezpośrednim impulsem dla intencji behawioralnej (Perugini, Bagozzi, 2001, s. 80). Intencja behawioralna (pozostając pod wpływem wcześniejszych doświadczeń i postrzeganego poziomu łatwości danego procesu) w połączeniu z najświeższymi doświadczeniami zakupowymi konsumenta stanowi najbliższe i zarazem najlepsze predyktory jego przyszłego zachowania, co jednak oznacza, że mimo korelacji z przyszłym zachowaniem nadal o nim nie przesądza. Gotowość do działania zostanie aktywizowana i będzie skutkowała określonym zachowaniem w momencie, gdy pojawią się czynniki sytuacyjne sprzyjające lub nieograniczające zachowania zgodnego z intencją ukierunkowaną przez postawę (rys. 1).

Z punktu widzenia mechanizmu oddziaływania wizerunku na zachowania konsumentów skupić się należy na kilku aspektach tego modelu. Punktem wyjścia w modelu Peruginiego i Bagozziniego, są postawy względem zachowania, oczekiwane emocje oraz normy subiektywne. Postawa względem marki, kształtowana pod wpływem poznawczego i emotywnego charakteru 
oddziaływania wizerunku marki, wiązała się będzie z wytworzeniem postawy wobec zachowania w stosunku do tej marki. Badania dowodzą, że w przypadku wielu produktów konsumenci wybierają marki o wizerunku spójnym z ich własnym wizerunkiem (obecnym lub pożądanym). Wizerunek użytkowanej marki pozwala im wyrazić siebie, kim są, jacy są i jakimi chcą być postrzegani (Graeff, 1997, s. 50; Grzegorczyk, 2005b, s. 151). Wizerunek oferowanej na rynku marki może w powiązaniu z wizerunkiem kraju pochodzenia marki (rzeczywistego lub sugerowanego) wywoływać zachowania konsumenta odzwierciedlające jego stosunek do danego kraju (pozytywny lub negatywny), natomiast silne skojarzenie cech wizerunku marki z krajem pochodzenia konsumenta może wpisać się w zjawisko etnocentryzmu, czyli manifestowania przez nabywców postaw patriotycznych przez decyzje zakupowe (Liczmańska, 2010, s. 180).

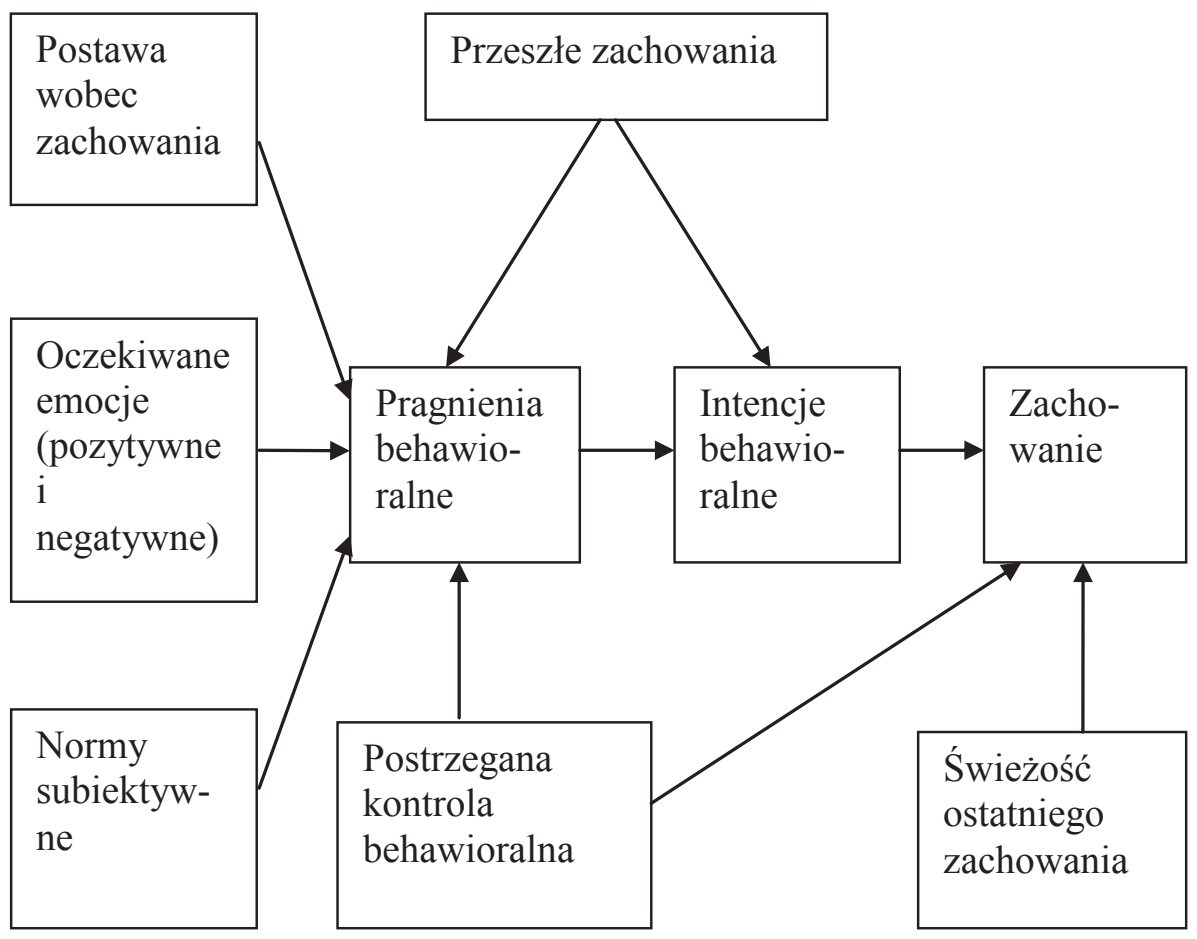

Rysunek 1. Model zachowania intencjonalnego - goal-directed behaviour (MGB)

Źródło: Perugini, Bagozzi, 2001, s. 80. 
Obok postawy pojawiają się jeszcze normy subiektywne, które odnoszą się do przeświadczenia danej jednostki o tym, że dane zachowanie jest akceptowane lub nawet pożądane przez grupę społeczną i jednocześnie jednostce tej zależy na akceptacji ze strony grupy. Korzystny w danej grupie społecznej wizerunek marki, niosący ze sobą treść symbolizującą aprobowane lub wręcz pożądane w danej grupie społecznej wartości, będzie stanowił dla jednostki obietnicę integracji z grupą przez asymilację, a zatem kształtował będzie jej intencję zakupową, pozwalającą przewidzieć zachowanie. Badania prowadzane przez Liczmańską dowodzą, że siła marki, tkwiąca m.in. w cechach jej wizerunku, symbolicznych znaczeniach pozwalających na wyrażanie przynależności do grupy docelowej, mają istotne znaczenie dla zachowania konsumentów na rynku (Liczmańska, 2008, s. 94).

Trzecia zmienna to oczekiwane emocje związane z zachowaniem. Wizerunek marki ma potencjał transformacji doznań podczas konsumpcji - korzystny wizerunek, akceptowany przez grupę społeczną i daną jednostkę, stymulował będzie oczekiwania co do pozytywnych emocji związanych z zakupem i użytkowaniem marki i analogicznie - wizerunek niekorzystny wiązał się będzie z oczekiwaniem emocji negatywnych.

\section{PODSUMOWANIE}

Podsumowując, mechanizm oddziaływania wizerunku marki na zachowania konsumentów wyjaśnić można na gruncie modeli zachowań nabywców opartych na postawach. Wizerunek marki może być celowo kształtowanym instrumentem, który w procesie zachowania się konsumenta na rynku:

- dostarcza konsumentom informacji, skracając etap poszukiwania informacji;

- gwarantuje pewne parametry oferty, obniżając subiektywnie postrzegane ryzyko zakupowe;

- wzbudza emocje;

- budzi skojarzenia;

- wzbogaca doznania konsumpcji;

- symbolizuje wartości lub ma atrybuty pozwalające utożsamić się konsumentowi z grupą społeczną;

- pomaga realizować własny system wartości.

Pełniąc wskazana powyżej funkcję wizerunek może wywoływać zjawisko rozprzestrzeniania się świadomości marki (np. przez polecanie). Badania empiryczne wykazują też wysoką korelację pomiędzy korzystnym wize- 
runkiem marki a zachowaniem lojalnościowym konsumentów (Chia-Hung, 2008, s. 243). Zjawisko lojalności, a nawet tworzenia się społeczności wokół marki zachodzi, jeśli wartości związane z wizerunkiem danej marki są spójne z systemem wartości konsumenta. W marketingu wagi nabiera zatem nie tylko identyfikacja potrzeb, które można zaspokoić odpowiednio zaprojektowanym produktem. Kluczowe wydaje się dziś identyfikowanie poszukiwanych przez konsumentów wartości, emocji, które następnie zostaną zaoferowane w postaci celowo ukształtowanego wizerunku marki.

\section{LITERATURA}

Altkorn J. (1999), Strategia marki, Polskie Wydawnictwo Ekonomiczne S.A., Warszawa.

Budzyński W. (2002), Wizerunek firmy, kreowanie, zarzadzanie efekty, Poltext, Warszawa.

Chia-Hung (2008), The Effect of Brand Image on Public Relations Perceptions and Customer Loyalty, „International Joumal of Management”, vol. 25, No. 2, June.

Cian (2011), How to measure brand image: a reasoned review, „The Marketing Review", Vol. 11, No. 2.

Edwards H. (2006), Day D., Kreowanie marek z pasja, Oficyna Ekonomiczna, Kraków.

Graeff T.R. (1997), Consumption Situations and the Effects of Brand Image on Consumers 'Brand Evaluations, „Psychology \& Marketing”, Vol. 14(1): 49-70, January.

Grzegorczyk A. (2005a), Marka jest nazwa. Definiens marki, [w:] Instrumenty ksztattowania wizerunku marki, A. Grzegorczyk (red.), Wyższa Szkoła Promocji, Warszawa.

Grzegorczyk A. (2005b), Wizerunek marki jako narzędzie oddziaływania rynkowego, [w:] Instrumenty ksztaltowania wizerunku marki, A. Grzegorczyk (red.), Wyższa Szkoła Promocji, Warszawa.

Grzegorczyk A. (2010), Reklama, Polskie Wydawnictwo Ekonomiczne, Warszawa.

Kall J. (2001), Silna marka. Istota i kreowanie, Polskie Wydawnictwo Ekonomiczne, Warszawa.

Kall J., Kłeczek R., Sagan A. (2006), Zarzadzanie marka, Oficyna Ekonomiczna, Kraków.

Kozłowska A. (2011), Reklama. Techniki perswazyjne, Oficyna Wydawnicza Szkoła Główna Handlowa, Warszawa. 
K. Liczmańska (2010), Efekt kraju pochodzenia produktu a decyzje nabywcze konsumentów sektora alkoholi wysokoprocentowych, „Roczniki Ekonomiczne Kujawsko-Pomorskiej Szkoły Wyższej w Bydgoszczy”, Wydawnictwo Kujawsko-Pomorskiej Szkoły Wyższej w Bydgoszczy, Bydgoszcz 2010, nr 3.

K. Liczmańska (2008), Silna marka jako źródto przewagi konkurencyjnej w momencie zakupu, „Roczniki Ekonomiczne Kujawsko-Pomorskiej Szkoły Wyższej w Bydgoszczy", Wydawnictwo Kujawsko-Pomorskiej Szkoły Wyższej w Bydgoszczy, Bydgoszcz 2008, nr 1.

Maison D. (2004), Utajone postawy konsumenckie, Gdańskie Wydawnictwo Psychologiczne, Gdańsk.

Nicosia F. M. (1968), Advertising management, consumer behavior, and simulation, „Journal of Advertising Research”, No 1, March.

Pars S. R., Gulsel C. (2011), The Effects of Brand Image on Consumers' Choice, „International Journal of Business and Social Science", vol. 2, No. 20, November.

Perugini M., Bagozzi R. P. (2001), The role of desires and anticipated emotions in goal-directed behaviours: Broadening and deepening the theory of planned behavior, „British Journal of Social Psychology”, $\mathrm{nr} 40$.

Rudnicki L. (2000), Zachowania konsumentów na rynku, Polskie Wydawnictwo Ekonomiczne, Warszawa, s. 83.

Urbanek G. (2002), Zarzadzanie marka, Polskie Wydawnictwo Ekonomiczne, Warszawa.

Zimbardo Ph. G., Leippe M. R. (2004), Psychologia zmiany postaw $i$ wptywu społecznego, Zysk i S-ka Wydawnictwo, Poznań.

\section{THE IMPACT MECHANISM OF BRAND IMAGE ON CONSUMER BEHAVIOR}

A b stract. Brand to the business community is one of the key elements of the market offer and compete. Businesses make an effort aimed at creating the image, but the legitimacy of these actions can be confirmed only by the full potential located in the created image. The author argues that the brand's image is an important factor influencing the behavior and purchasing decisions of consumers, and a number of functions attributed to the brand are provided by the features of the image.

K e y w o rd s: brand image, consumer behavior, attitudes. 